\title{
Fully Hydrophobic Artificial Protein but Water Dispersible due to Large Dipole
}

\author{
Makoto FukudA, ${ }^{1}$ Junji SugiYama, ${ }^{2}$ Tomoyuki Morita, ${ }^{1}$ and Shunsaku KIMURA ${ }^{1, \dagger}$ \\ ${ }^{1}$ Department of Material Chemistry, Graduate School of Engineering, Kyoto University, \\ Kyoto-Daigaku-Katsura, Nishikyo-ku, Kyoto 615-8510, Japan \\ ${ }^{2}$ Research Institute of Sustainable Humanosphere, Kyoto University, Gokanosho, Uji 611-0011, Japan
}

(Received November 14, 2005; Accepted December 20, 2005; Published April 15, 2006)

\begin{abstract}
Three-arm helices (TA16, TA8), in which three hydrophobic helical peptides were tethered together at their C-terminals, were synthesized, and self-assembling property in water was investigated. TA16 (m.w. $=5228)$ was dispersed easily in water even though this compound has no explicit hydrophilic moiety in the molecule. Dynamic light scattering measurement and transmission electron microscopy images of water dispersions of TA16 and TA8 revealed that spherical assemblies with diameter of $70 \mathrm{~nm}$ (TA16) and $100 \mathrm{~nm}$ (TA8) were formed. The central tertiary amine moiety in TA16 and TA8 should act as a hydrophilic part due to the convergent point of the three negatively polarized C-terminals of helices. [DOI 10.1295/polymj.38.381]

KEY WORDS Polypeptide / Self Assembly / Dipole Moment / Hydrophilicity /
\end{abstract}

Amphiphilic polymers have been demonstrated to form various molecular assemblies in water with taking morphologies of micelle, fibril, and vesicle. ${ }^{1-5}$ Helical peptide vesicle, peptosome, ${ }^{6-8}$ is one of such examples, and has a unique property of highly ordered structure formed in the hydrophobic peptide layer. Formerly, hydrophobic helical peptides were connected with hydrophilic groups such as an ammonium group, ${ }^{6}$ poly(ethyleneoxide), ${ }^{7}$ or disaccharide ${ }^{8}$ to bear the amphiphilicity in molecule. In the present study, three hydrophobic helical peptides are just connected together at the $\mathrm{C}$ terminals with a shape of three-arm helix, and the hydrophobic peptides were found to be dispersible in water. Notably, the peptides do not carry any explicit hydrophilic moieties in the molecules.

Two kinds of three-arm helix peptides were synthesized (Figure 1). TA16 is composed of three hydrophobic helical heptadecapeptides with a 2-naphthylacetyl group at the $\mathrm{N}$ terminal, where three helices are connected together using triaminopropylamine as a core. TA8 is composed of three hydrophobic helical nonapeptides in a similar way as TA16. These compounds are expected to show some characteristic properties due to large dipole moments of the helices. Previously, we reported a derivative of TA16 with three additional hydrophilic peptide chains formed an ion channel in lipid membrane, and we named it "peptide umbrella." Here, TA16 is newly synthesized and the novel property due to dipole moment was investigated in detail.

\section{EXPERIMENTAL}

Synthesis of Helical Peptides TA16, TA8 and a Reference Compound TAA

TA16, TA8 (Figure 1) and TAA $\left(\left(\mathrm{CH}_{3}\left(\mathrm{CH}_{2}\right)_{11} \mathrm{CO}-\right.\right.$ Lys( $\left.\mathrm{Z})-\mathrm{NHCH}_{2} \mathrm{CH}_{2} \mathrm{CH}_{2}\right)_{3}-\mathrm{N}$ ) were synthesized according to Scheme 1. All peptides were synthesized by the conventional liquid-phase method. Boc-(LAla-Aib) $)_{4}-\mathrm{OBzl}$ (BA8B) and Boc-(L-Ala-Aib) ${ }_{8}-\mathrm{OBzl}$ (BA16B) were synthesized by the methods in the literature. ${ }^{10}$ All intermediates and final products were

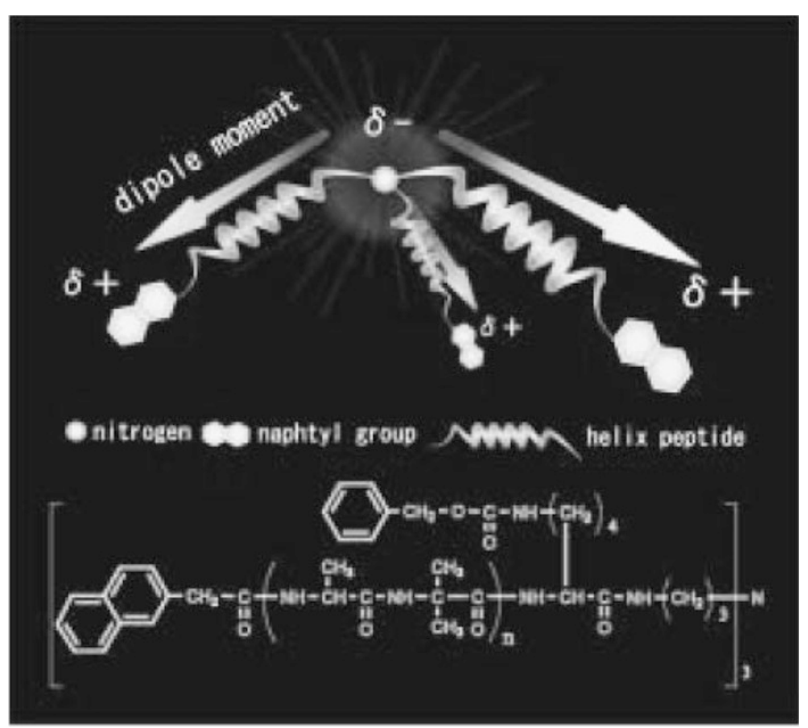

Figure 1. Chemical structure of the three-arm helix $(n=8$ : TA16 $n=4$ : TA8).

${ }^{\dagger}$ To whom correspondence should be addressed (E-mail: shun@scl.kyoto-u.ac.jp). 

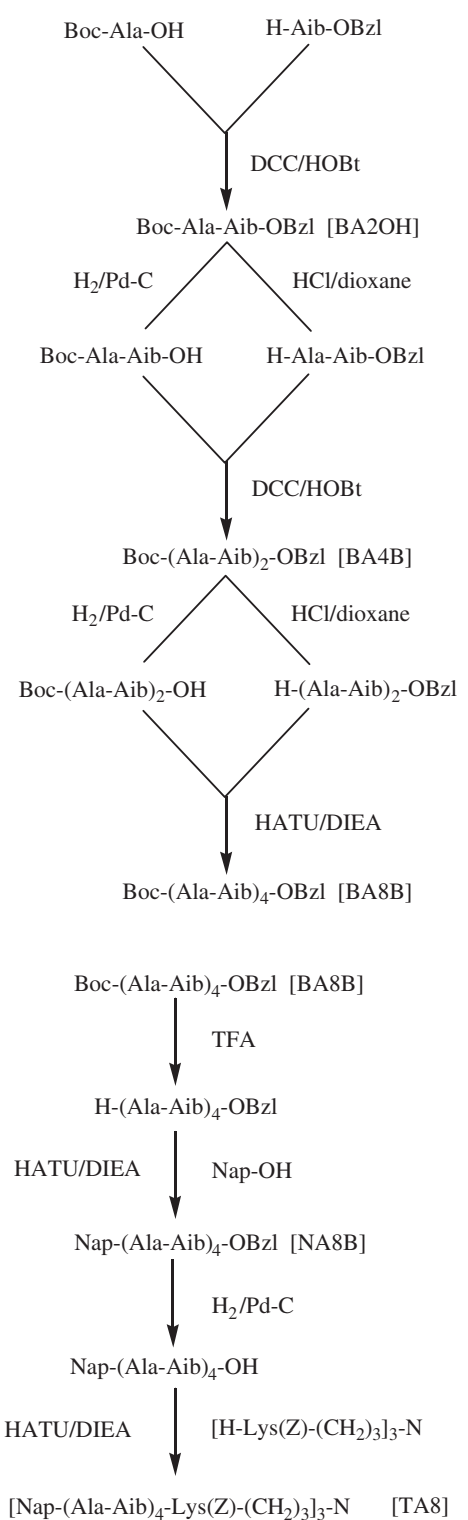

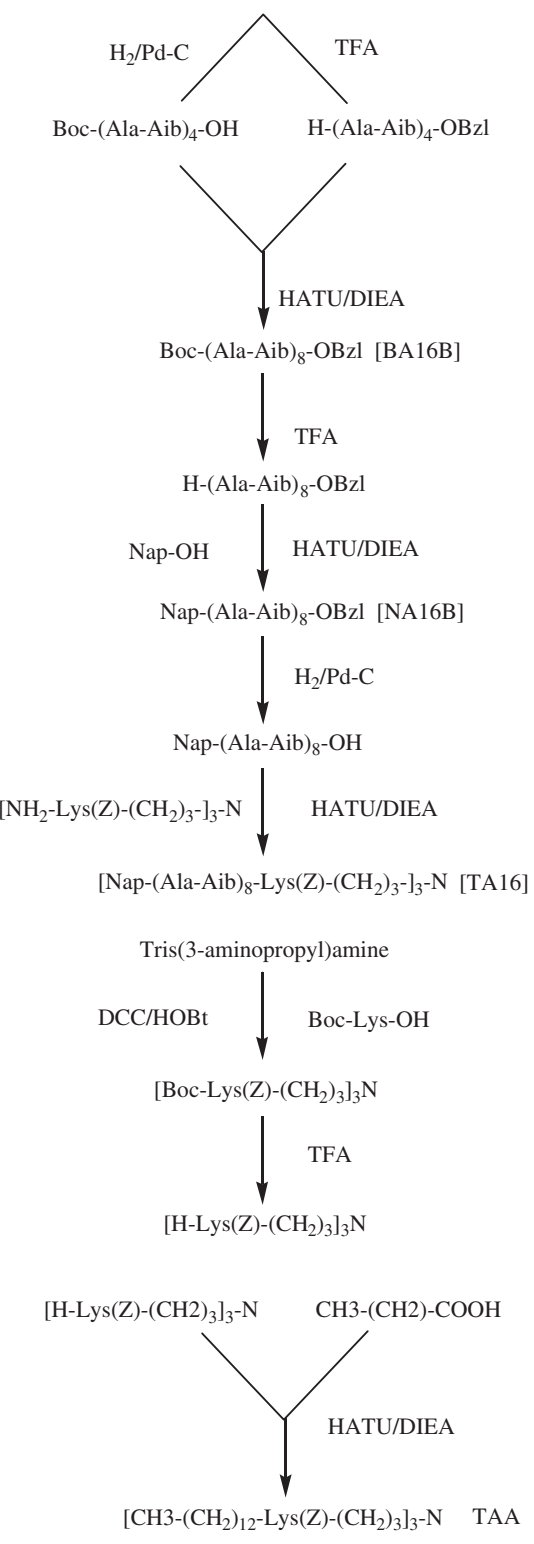

Scheme 1. Synthetic schemes of TA16, TA8, and TAA.

identified by ${ }^{1} \mathrm{H}$ NMR (400 MHz), and their purity was checked by thin-layer chromatography (TLC). The final products were further confirmed by mass spectroscopy. Details of the syntheses are as follows.

\section{(Boc-Lys(Z)-NH-( $\left.\left.\mathrm{CH}_{2}\right)_{3}\right)_{3}-\mathrm{N}$}

Boc-Lys(Z)-OH was dissolved in DMF and reacted with tris(3-aminopropyl)amine using $N, N^{\prime}$-dicyclohexylcarbodiimide (DCC) and 1-hydroxybenzotriazole (HOBt) as coupling reagent. The reaction solution was then washed successively with $4 \mathrm{wt} \%$ $\mathrm{NaHCO}_{3}, 4$ wt $\% \mathrm{KHSO}_{4}$, and saturated $\mathrm{NaCl}$ aqueous solutions. The organic phase was separated and dried over $\mathrm{MgSO}_{4}$, the solvent was evaporated, and the crude product was purified by a Sephadex LH20 column using methanol as eluent. The residue was washed with diethyl ether and $n$-hexane.

${ }^{1} \mathrm{H} \mathrm{NMR}\left(\mathrm{CDCl}_{3}, 300 \mathrm{MHz}\right): \delta(\mathrm{ppm}) 1.32-2.07(57 \mathrm{H}$,
$\left(\mathrm{CH}_{3}\right)_{3} \mathrm{C}, \mathrm{LysC}^{\beta} \mathrm{H}_{2}, \mathrm{LysC}^{\gamma} \mathrm{H}_{2}, \mathrm{LysC}^{\delta} \mathrm{H}_{2}, \mathrm{~N}\left(\mathrm{CH}_{2} \mathrm{CH}_{2}-\right.$ $\left.\left.\mathrm{CH}_{2}\right)_{3}, \mathrm{~N}\left(\mathrm{CH}_{2} \mathrm{CH}_{2} \mathrm{CH}_{2}\right)_{3}\right), 3.20-3.35\left(12 \mathrm{H}, \mathrm{N}\left(\mathrm{CH}_{2}-\right.\right.$ $\left.\left.\mathrm{CH}_{2} \mathrm{CH}_{2}\right)_{3}, \mathrm{LysC}^{\varepsilon} \mathrm{H}_{2}\right), 4.08\left(3 \mathrm{H}, \mathrm{LysC}^{\alpha} H\right), 5.09(6 \mathrm{H}, \mathrm{s}$, $\left.\mathrm{OCH}_{2} \mathrm{C}_{6} \mathrm{H}_{5}\right), 5.50-5.67\left(6 \mathrm{H}\right.$, Lys $(\mathrm{CH})_{4} \mathrm{NH}$, LysNH), $7.30\left(5 \mathrm{H}, \mathrm{OCH}_{2} \mathrm{C}_{6} \mathrm{H}_{5}\right), 7.88\left(3 \mathrm{H}, \mathrm{N}\left(\mathrm{CH}_{2} \mathrm{CH}_{2} \mathrm{CH}_{2}-\right.\right.$ $\mathrm{NH})_{3}$ ).

MS (FAB, matrix; nitrobenzylalcohol): $\mathrm{m} / \mathrm{z} 1275$ (calcd for $\mathrm{C}_{66} \mathrm{H}_{102} \mathrm{~N}_{10} \mathrm{O}_{15}\left[(\mathrm{M}+\mathrm{H})^{+}\right] m / z$ 1275).

\section{$N A 16 B$}

The Boc group of BA16OBzl was removed by treatment with TFA. The product was dissolved in DMF and reacted with 2-naphthaleneacetic acid in the presence of HATU with DIEA. After the solvent was removed, the remaining crude product was purified by a Sephadex LH20 column using methanol as eluent. The residue was washed with diethyl ether and $n$-hexane. 
${ }^{1} \mathrm{H}$ NMR (400 MHz, $\left.\mathrm{CDCl}_{3}\right): \delta(\mathrm{ppm}) 1.42-1.65(72 \mathrm{H}$, $\left.\mathrm{AlaC} \beta \mathrm{H}_{3}, \mathrm{AibCH}_{3}\right), 3.70\left(2 \mathrm{H}, \mathrm{s}, \mathrm{C}_{10} \mathrm{H}_{7} \mathrm{CH}_{2}\right), 3.92-$ $4.28(8 \mathrm{H} \mathrm{AlaC} \alpha H), 5.11\left(2 \mathrm{H}, \mathrm{s}, \mathrm{OCH}_{2} \mathrm{C}_{6} \mathrm{H}_{5}\right), 6.58$, 7.29-8.77 (28H, naphthyl- $H, \mathrm{OCH}_{2} \mathrm{C}_{6} H_{5}, \mathrm{AlaNH}$, AibNH).

MS (FAB, matrix; nitrobenzylalcohol): $\mathrm{m} / \mathrm{z} 1548$ (calcd for $\mathrm{C}_{75} \mathrm{H}_{112} \mathrm{~N}_{16} \mathrm{O}_{18}\left[(\mathrm{M}+\mathrm{Na})^{+}\right] \mathrm{m} / z$ 1548).

NA8B (This was synthesized similarly to the case of TA16.)

${ }^{1} \mathrm{H}$ NMR $\left(400 \mathrm{MHz}, \mathrm{CDCl}_{3}\right): \delta(\mathrm{ppm}) 1.42-1.64(36 \mathrm{H}$, $\mathrm{AlaC} \beta H 3$, AibCH3), $3.64\left(2 \mathrm{H}, \mathrm{s}, \mathrm{C}_{10} \mathrm{H}_{7} \mathrm{CH}_{2}\right), 3.92-$ $4.38(8 \mathrm{H} \mathrm{AlaC} \alpha H), 5.19\left(2 \mathrm{H}, \mathrm{s}, \mathrm{OCH}_{2} \mathrm{C}_{6} \mathrm{H}_{5}\right), 6.63$, 7.12-7.85 (28H, naphthyl- $H$, OCH2C6H5, AlaNH, AibNH).

MS (FAB, matrix; nitrobenzylalcohol): $\mathrm{m} / \mathrm{z} 923$ (calcd for $\mathrm{C}_{47} \mathrm{H}_{64} \mathrm{~N}_{8} \mathrm{O}_{10}\left[(\mathrm{M}+\mathrm{Na})^{+}\right] m / z$ 923).

\section{TA16}

The benzyl group of NA16B was removed by the catalytic hydrogenation in dichloromethane with 10 wt $\%$ palladium carbon and washed with diethyl ether and $n$-hexane. The product was dissolved in DMF and reacted with (H-Lys(Z)-NH- $\left.\left(\mathrm{CH}_{2}\right)_{3}\right)_{3}-\mathrm{N}$ in the presence of HATU with DIEA. After the solvent was removed, the remaining crude product was purified by Sephadex LH60 and LH20 columns using a mixed solution (chloroform/methanol $=1 / 1 \mathrm{v} / \mathrm{v}$ ) and the residue was washed with diethyl ether and $n$-hexane.

${ }^{1} \mathrm{H}$ NMR $\left(\mathrm{CDCl}_{3}, \quad 300 \mathrm{MHz}\right): \delta$ (ppm) $1.25-2.10$ $\left(246 \mathrm{H}, \mathrm{AlaC}^{\beta} \mathrm{H}_{3}, \mathrm{AibCH}_{3}, \mathrm{LysC}^{\beta} \mathrm{H}_{2}, \mathrm{LysC}^{\gamma} \mathrm{H}_{2}\right.$, Lys$\left.\mathrm{C}^{\delta} \mathrm{H}_{2}, \quad \mathrm{~N}\left(\mathrm{CH}_{2} \mathrm{CH}_{2} \mathrm{CH}_{2}\right)_{3}, \quad \mathrm{~N}\left(\mathrm{CH}_{2} \mathrm{CH}_{2} \mathrm{CH}_{2}\right)_{3}\right), \quad 3.07-$ $3.22\left(12 \mathrm{H}, \mathrm{N}\left(\mathrm{CH}_{2} \mathrm{CH}_{2} \mathrm{CH}_{2}\right)_{3}\right.$, $\left.\mathrm{LysC}^{\varepsilon} \mathrm{H}_{2}\right), 3.66-4.04$ $\left(33 \mathrm{H}, \mathrm{AlaC}^{\alpha} \mathrm{H}, \mathrm{LysC}^{\alpha} \mathrm{H}, \mathrm{C}_{10} \mathrm{H}_{7} \mathrm{CH}_{2}\right), 5.00(6 \mathrm{H}, \mathrm{s}$, $\left.\mathrm{OCH}_{2} \mathrm{C}_{6} \mathrm{H}_{5}\right), 6.15\left(3 \mathrm{H}, \mathrm{N}\left(\mathrm{CH}_{2} \mathrm{CH}_{2} \mathrm{CH}_{2} \mathrm{NH}\right)_{3}\right), 7.38-$ $7.43\left(3 \mathrm{H}, \quad \operatorname{Lys}(\mathrm{CH})_{4} \mathrm{NH}\right), 7.27,7.44-7.84(87 \mathrm{H}$, $\mathrm{OCH}_{2} \mathrm{C}_{6} H_{5}$, AlaN $H$, AibN $H$, LysN $H$, naphthyl- $H$ ).

MS (FAB, matrix; nitrobenzylalcohol): $\mathrm{m} / \mathrm{z} 5226$ (calcd for $\mathrm{C}_{255} \mathrm{H}_{390} \mathrm{~N}_{58} \mathrm{O}_{60}\left[(\mathrm{M}+\mathrm{H})^{+}\right] \mathrm{m} / z$ 5226).

\section{TA8}

The benzyl group of NA8B was removed by the catalytic hydrogenation in dichloromethane with $10 \mathrm{wt} \%$ palladium carbon and washed with diethyl ether and $n$-hexane. The product was dissolved in DMF and reacted with (H-Lys( $\left.\mathrm{Z})-\mathrm{NH}-\left(\mathrm{CH}_{2}\right)_{3}\right)_{3}-\mathrm{N}$ in the presence of HATU with DIEA. After the solvent was removed, the remaining crude product was purified by Sephadex LH60 and LH20 columns using a mixed solution (chloroform $/$ methanol $=1 / 1 \mathrm{v} / \mathrm{v}$ ) and the residue was washed with ethyl ether and $n$ hexane.

${ }^{1} \mathrm{H}$ NMR $\left(\mathrm{CDCl}_{3}, \quad 300 \mathrm{MHz}\right): \delta \quad(\mathrm{ppm}) \quad 1.25-2.02$ $\left(138 \mathrm{H}, \mathrm{AlaC}^{\beta} \mathrm{H}_{3}, \mathrm{AibCH}_{3}, \mathrm{LysC}^{\beta} \mathrm{H}_{2}, \mathrm{LysC}^{\gamma} \mathrm{H}_{2}\right.$, Lys$\left.\mathrm{C}^{\delta} \mathrm{H}_{2}, \mathrm{~N}\left(\mathrm{CH}_{2} \mathrm{CH}_{2} \mathrm{CH}_{2}\right)_{3}, \mathrm{~N}\left(\mathrm{CH}_{2} \mathrm{CH}_{2} \mathrm{CH}_{2}\right)_{3}\right), 3.07-$ $3.22\left(12 \mathrm{H}, \mathrm{N}\left(\mathrm{CH}_{2} \mathrm{CH}_{2} \mathrm{CH}_{2}\right)_{3}, \mathrm{LysC}^{\varepsilon} \mathrm{H}_{2}\right), 3.66-4.04$ $\left(21 \mathrm{H}, \mathrm{AlaC}^{\alpha} \mathrm{H}, \mathrm{LysC}^{\alpha} \mathrm{H}, \mathrm{C}_{10} \mathrm{H}_{7} \mathrm{CH}_{2}\right), 5.00(6 \mathrm{H}, \mathrm{s}$, $\left.\mathrm{OCH}_{2} \mathrm{C}_{6} \mathrm{H}_{5}\right), 6.15\left(3 \mathrm{H}, \mathrm{N}\left(\mathrm{CH}_{2} \mathrm{CH}_{2} \mathrm{CH}_{2} \mathrm{NH}\right)_{3}\right), 7.38-$ $7.43\left(3 \mathrm{H}, \quad \operatorname{Lys}(\mathrm{CH})_{4} \mathrm{NH}\right), 7.27,7.44-7.84(63 \mathrm{H}$, OCH2C6H5, AlaNH, AibN $H$, LysN $H$, naphthyl- $H$ ). MS (FAB, matrix; nitrobenzylalcohol): $\mathrm{m} / z 3353$ (calcd for $\mathrm{C}_{171} \mathrm{H}_{246} \mathrm{~N}_{34} \mathrm{O}_{36}\left[(\mathrm{M}+\mathrm{H})^{+}\right] \mathrm{m} / z$ 3353).

TAA

Dodecanoic acid was dissolved in DMF and reacted with (H-Lys $\left.(\mathrm{Z})-\mathrm{NH}-\left(\mathrm{CH}_{2}\right)_{3}\right)_{3}-\mathrm{N}$ in the presence of HATU with DIEA. After $24 \mathrm{~h}$, the precipitate was filtered and washed with DMF, methanol, diethyl ether and $n$-hexane.

${ }^{1} \mathrm{H} \mathrm{NMR}\left(\mathrm{CDCl}_{3}, 300 \mathrm{MHz}\right): \delta(\mathrm{ppm}) 0.84(9 \mathrm{H}, \mathrm{t}$, $\left.\mathrm{CH}_{2}\left(\mathrm{CH}_{2}\right)_{10} \mathrm{CH}_{3}\right), 1.24\left(66 \mathrm{H}, \mathrm{m}, \mathrm{CH}_{2}\left(\mathrm{CH}_{2}\right)_{10} \mathrm{CH}_{3}\right)$, 1.47-1.69 (24H, LysC ${ }^{\beta} H_{2}$, LysC ${ }^{\gamma} H_{2}$, LysC ${ }^{\delta} H_{2}$, N$\left.\left(\mathrm{CH}_{2} \mathrm{CH}_{2} \mathrm{CH}_{2}\right)_{3}\right), 2.17\left(6 \mathrm{H}, \mathrm{N}\left(\mathrm{CH}_{2} \mathrm{CH}_{2} \mathrm{CH}_{2}\right)_{3}\right), 3.08-$ $3.19\left(12 \mathrm{H}, \mathrm{N}\left(\mathrm{CH}_{2} \mathrm{CH}_{2} \mathrm{CH}_{2}\right)_{3}, \mathrm{LysC}^{\varepsilon} \mathrm{H}_{2}\right), 4.31(3 \mathrm{H}$, LysC $\left.^{\alpha} H\right), 5.02\left(6 \mathrm{H}, \mathrm{s}, \mathrm{OCH}_{2} \mathrm{C}_{6} \mathrm{H}_{5}\right), 6.15$ (3H, Lys$\left.(\mathrm{CH})_{4} \mathrm{NH}\right), 7.38-7.43(21 \mathrm{H}, \mathrm{OCH} 2 \mathrm{C} 6 \mathrm{H} 5, \mathrm{LysNH}$, $\left.\mathrm{N}\left(\mathrm{CH}_{2} \mathrm{CH}_{2} \mathrm{CH}_{2} \mathrm{NH}\right)_{3}\right)$.

MS (FAB, matrix; nitrobenzylalcohol): $\mathrm{m} / z$ (calcd for $\mathrm{C}_{90} \mathrm{H}_{151} \mathrm{~N}_{10} \mathrm{O}_{12}\left[(\mathrm{M}+\mathrm{H})^{+}\right] m / z$ 1564).

\section{Preparation of Peptide Dispersion in Water}

The water dispersion of TA16 was prepared by injection of an ethanol solution $(100 \mu \mathrm{L})$ into ultra-pure water $(1.9 \mathrm{~mL})$ at $0{ }^{\circ} \mathrm{C}$. The dispersion was very stable and did not precipitate for more than 2 months. TA8 dispersion was prepared by injection of an ethanol solution $(100 \mu \mathrm{L})$ into $100^{\circ} \mathrm{C}$ ultra-pure water $(1.9 \mathrm{~mL})$, but the dispersion was not so stable as the TA16 dispersion. About TAA, 1,1,1,3,3,3-hexafluoroisopropanol (HFIP) solution $(100 \mu \mathrm{L})$ was injected into $100^{\circ} \mathrm{C}$ ultra-pure water $(1.9 \mathrm{~mL})$. This dispersion was unstable and precipitate was observed after a few weeks.

\section{Frozen-hydrated/cryo-transmission Electron Micro- scopy (cryo-TEM)}

The peptide dispersions in water were frozen quickly in liquid propane, which was cooled with liquid nitrogen. This sample was examined with a JEOL JEM$2000 \mathrm{EX}$ at $100 \mathrm{kV}$ accelerating voltage at the liquid nitrogen temperature under low-dose conditions.

\section{Circular Dichroism (CD) and Fluorescence Measure- ments}

$\mathrm{CD}$ and fluorescence measurements were carried out on a JASCO J600 spectropolarimeter using an optical cell of $0.1 \mathrm{~cm}$ optical path length and a Hitachi F-4010 fluorospectrometer, respectively.

\section{Dynamic Light Scattering}

The peptide dispersions were subjected to dynamic light scattering measurements (DLS-7000, Otsuka 

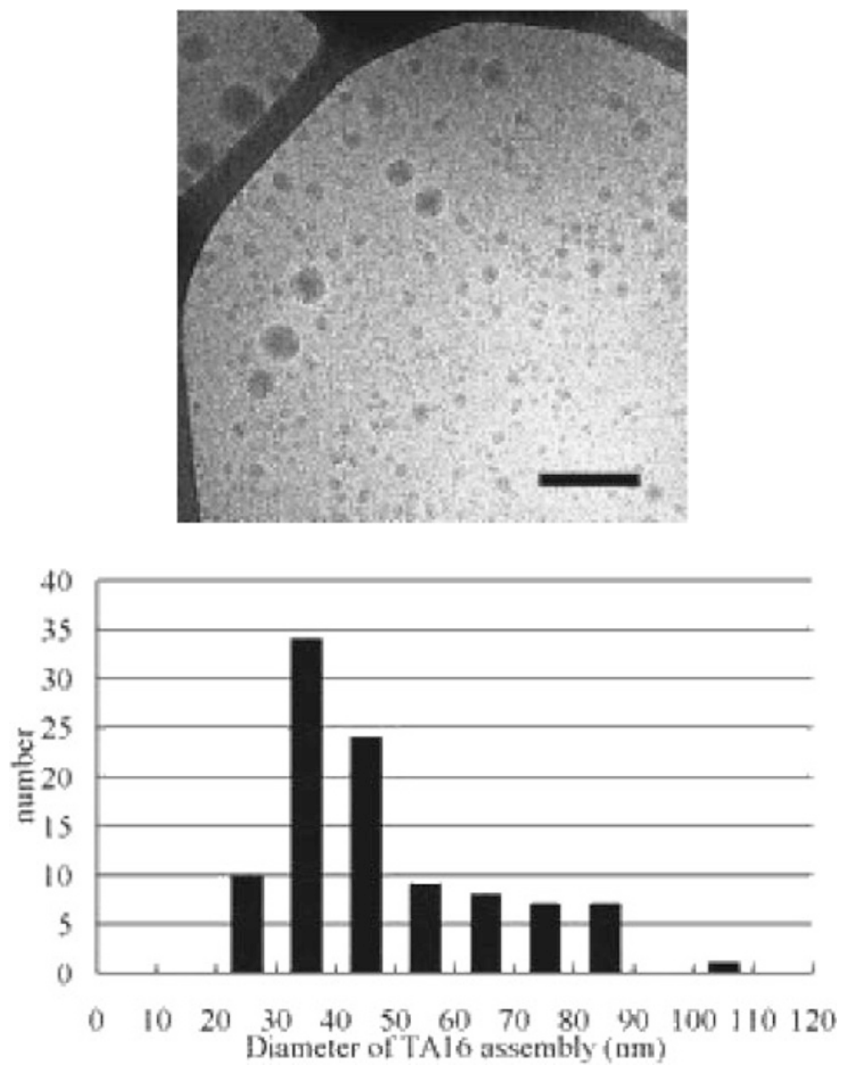

Figure 2. Cryo-TEM image of TA16 dispersion in water (top). Bar $=200 \mathrm{~nm}$. The size distribution of TA16 assembly (bottom).

Electronics Co. Ltd., Japan). Vertically polarized light of wavelength $632.8 \mathrm{~nm}$ from a He-Ne laser was used as the incident beam. All measurements were performed at $25^{\circ} \mathrm{C}$.

\section{RESULTS AND DISCUSSION}

An ethanol solution of TA16 was injected into an ice-cold pure water under stirring to obtain the peptide dispersion (5\% ethanol/95\% water; $\mathrm{v} / \mathrm{v}$ ). No precipitate formation was observed for more than two months at room temperature. On the other hand, an ethanol solution of TA8 had to be injected into a boiling pure water to obtain a stable dispersion, which did not yield precipitate with cooling down to room temperature. It should be noted that the apparently larger and more hydrophobic TA16 (m.w. 5,228) forms selfassembly in water easier and more stably than TA8 (m.w. 3,354). The water dispersions of these peptides were analyzed by CD spectroscopy, showing that these peptides adopted $\alpha$-helical conformation, which means that most of the amide groups in the peptides are shielded from water by intramolecular hydrogen bonds, and do not act as a hydrophilic group for the molecule. Therefore, the amide bonds can not explain as hydrophilic moieties for formation of the stable
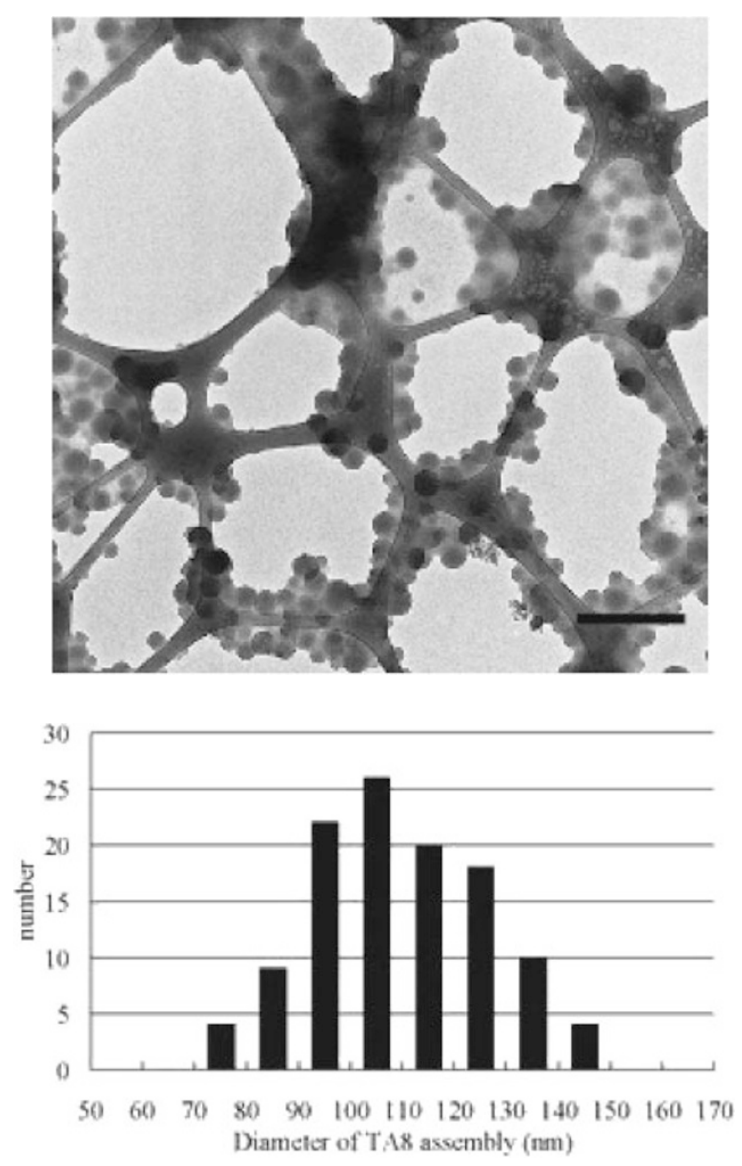

Figure 3. Cryo-TEM image of TA8 dispersion in water (top). Bar $=500 \mathrm{~nm}$. The size distribution of TA 8 assembly (bottom).

self-assembly of TA16 in water.

The water dispersions of the peptides were frozen instantaneously and subjected to cryo-TEM observation. Spherical assemblies were clearly observed, and the average diameter was evaluated directly from the TEM images as 48 and $109 \mathrm{~nm}$ for TA16 (Figure 2) and TA8 (Figure 3), respectively. DLS measurements also indicated formation of spherical assemblies with hydrodynamic diameters of 60 and $97 \mathrm{~nm}$ for TA16 and TA8, respectively, which are agreeable with the results of cryo-TEM. The spherical assembly of TA16 was stable in water for more than weeks as the hydrodynamic diameter did not change during the period.

Encapsulation experiment was carried out with the TA16 assembly (Figure 4). An ethanol solution of TA16 was injected into an aqueous solution of fluorescein-labelled dextran (m.w. about 4,000), and the dispersion was applied to a Sephacryl S100 column with using water/ethanol $(19 / 1) \mathrm{v} / \mathrm{v}$ as eluent. The elution profile clearly showed that the fractions of the TA16 assembly encapsulated dextran, indicating vesicular structure (peptosome). The same encapsulation experiment was also carried out with the TA8 assembly. We observed the two colored bands in the 


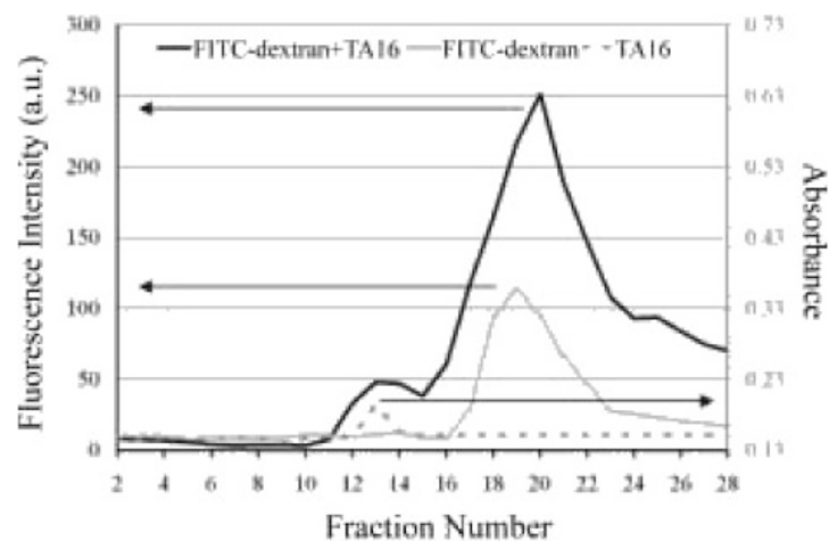

Figure 4. Elution profiles of TA16 assembly (broken line, detected by absorption at $280 \mathrm{~nm})$, TA16 assembly prepared with FITC-dextran in water (solid line, detected by fluorescence intensity at $515 \mathrm{~nm}$ ), and FITC-dextran in water (dotted line, detected by fluorescence intensity at $515 \mathrm{~nm}$ ) through a Sephacryl S100 column.

column, which should be ascribed to vesicles encapsulating the labeled dextran and free labeled dextran. However, the former band was stuck in the column during the operation, and the latter passed over the former band to elute out from the column. The TA8 vesicles therefore were not hydrophilic enough to elute out from the column.

The water dispersions of TA16 and TA8 were examined by fluorescence spectroscopy. TA16 showed mainly the monomer emission (Figure 5a), whereas TA8 in water showed a strong excimer emission (Figure 5b). In either case, the emission was hardly changed with the addition of water-soluble quencher (acrylamide). Therefore, the $\mathrm{N}$ terminal of the helices should be shielded inside of the molecular assembly. No excimer formation in the TA16 assembly may be explained by a loose molecular packing to avoid close contact of the naphthyl groups. On the other hand, the TA8 assembly should possess a tight molecular packing to cause excimer formation. This interpretation can be reasonably supported from the view point of dipole moment of a three-helix bundle and formation of bilayer with the peptides as follows. Three negative poles of the helices in TA16 are bound to the N atom, which comes to be extremely polar and acts as a hydrophilic site. The peptides should form a bilayer structure with exposing the $\mathrm{N}$ moiety to water phase and integrating the hydrophobic helical chains inside of bilayer. The hydrophilicy of the $\mathrm{N}$ moiety in TA16 is so large that it can balance the relatively expanded three helices as a hydrophobic site, leading to a loose packing of helices. On the other hand, the dipole strength of TA8 is nearly the half of TA16, resulting that the hydrophobic helices should shrink to make the helices pack tightly because of less hydrophilic property around the core $\mathrm{N}$ moiety.

At the moment, we can not provide a detailed explanation how the hydrophilic polar site can promote the hydration, but the polar site due to the dipole is found to be more effective in formation of the self assembly than a cation site, when the cation is introduced at the $\mathrm{N}$ atom in the three-arm helix as follows. An ethanol solution of TA16 was injected into a Tris$\mathrm{HCl}$ buffer (1 mM, pH 7.4). When the dispersion with negatively stained by uranyl acetate was observed by TEM, only aggregates of spherical assemblies with a few ten nm size were detected. It is thus concluded that cation at the tertiary amine moiety of a convergent point in TA16 is not so effective as a hydrophilic site to induce the water dispersible assembly when it is compared with the free tertiary amine moiety with strong negative poles of the three helices.

A reference compound, TAA $\left(\left(\mathrm{CH}_{3}\left(\mathrm{CH}_{2}\right)_{11} \mathrm{CO}\right.\right.$ Lys( $\mathrm{Z}$ ) $\left.-\mathrm{NHCH}_{2} \mathrm{CH}_{2} \mathrm{CH}_{2}\right)_{3}-\mathrm{N}$ ), which is composed of three dodecyl chains in stead of the three peptide units in TA16, was synthesized and examined on self-assembling property in water. A 1,1,1,3,3,3-hexafluoroisopropanol solution of TAA was injected into a boiling pure water to obtain a water dispersion. The dispersion was not so stable and yielded precipitate after

(a)

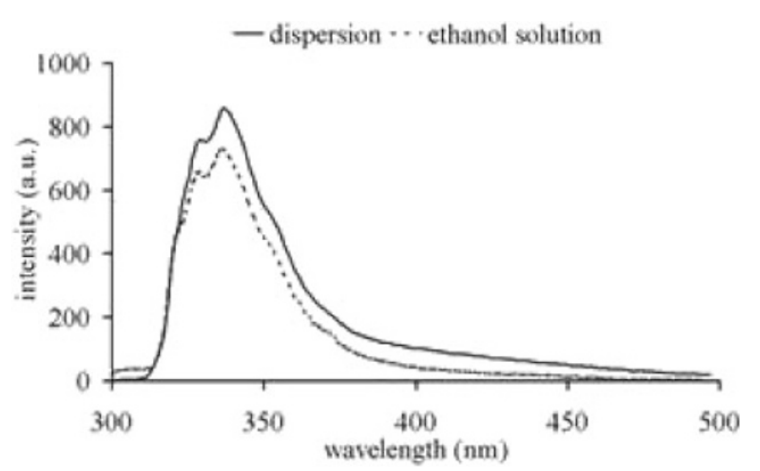

(b)

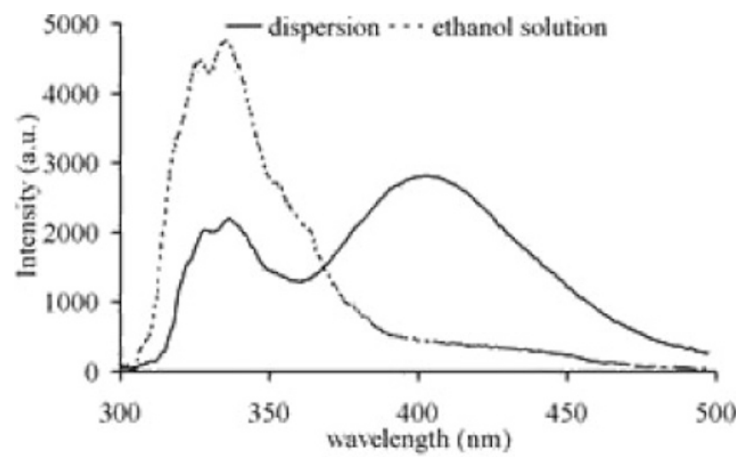

Figure 5. Fluorescence spectra of water dispersion and ethanol solution of TA16 (a) and TA8 (b). $\lambda_{\mathrm{ex}}=278 \mathrm{~nm}$. 


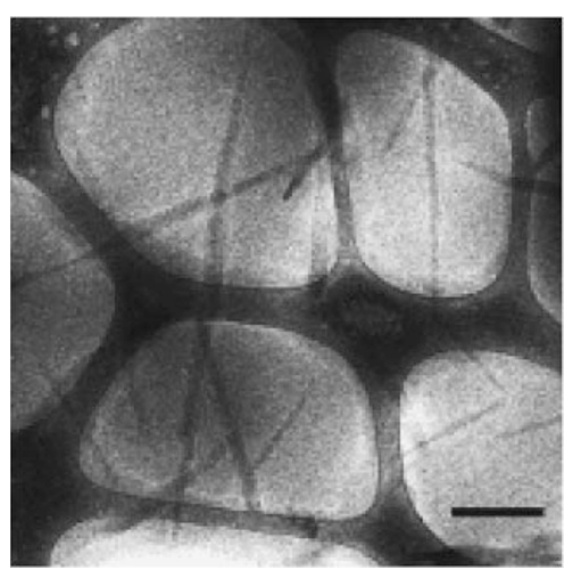

Figure 6. Cryo-TEM image of aqueous dispersion of TAA $(\mathrm{Bar}=300 \mathrm{~nm})$.

standing the dispersion at room temperature over a few weeks. Since TAA does not have any segments of large dipole moment, it is not equipped with hydrophilic property and was precipitated out with standing at room temperature. The cryo-TEM observation of the freshly prepared dispersion showed formation of needle-shaped assembly with $10-60 \mathrm{~nm}$ width and $\mu \mathrm{m}$ length (Figure 6), which makes a vivid contrast with the spherical assemblies of TA16 and TA8. From the needle-shaped morphology, the plausible molecular arrangement of the TAA assembly might be bundles of molecular threads where each thread should be formed by molecular stacking of TAA. Comparing the spherical assemblies of TA16 and TA8 with the needle-shaped assembly of TAA, the large dipole moment should be a critical factor to determine the morphology of the hydrophobic peptide assembly in water.

\section{CONCLUSIONS}

Water-soluble or -dispersible compounds should possess hydrophilic groups in the molecule for hydration. For example, insulin contains 15 hydrophilic amino acid residues out of 51 total residues. However, we find here an artificial protein composed of 51 amino acid residues without any explicit hydrophilic groups being water-dispersible. That is because the artificial protein forms a vesicular self-assembly in water with exposing hydrophilic surfaces due to the negative polar ends of helical peptides. Dipole moment has been used for molecular assembly but to regulate the structure due to the dipole interaction. ${ }^{11}$ In the present case, the molecules are endowed with hydrophilicity due to the large dipole moment, which should be a new concept for hydrophilicity.

Acknowledgment. The authors thank Professor Takao Itoh in Kyoto University for allowing us to use TEM and for technical advices. This work is financially supported by Grant-in-Aid for Young Scientists B (16750098), Grant-in-Aid for Scientific Research B and 21st century COE program, COE for a United Approach to New Materials Science, from the Ministry of Education, Culture, Sports, Science and Technology.

\section{REFERENCES}

1. B. Jeong, Y. H. Bae, D. S. Lee, and S. W. Kim, Nature, 388, 860 (1997).

2. K. Yu and A. Eisenberg, Macromolecules, 29, 6359 (1996).

3. J. Cornelissen, M. Fischer, N. Sommerdijk, and R. J. M. Nolte, Science, 280, 1427 (1998).

4. J. Cornelissen, A. E. Rowan, R. J. M. Nolte, and N. Sommerdijk, Chem. Rev., 101, 4039 (2001).

5. N. S. Cameron, M. K. Corbierre, and A. Eisenberg, Can. J. Chem., 77, 1311 (1999).

6. K. Fujita, S. Kimura, and Y. Imanishi, Langmuir, 15, 4377 (1999).

7. S. Kimura, D. H. Kim, J. Sugiyama, and Y. Imanishi, Langmuir, 15, 4461 (1999).

8. S. Kimura, Y. Muraji, J. Sugiyama, K. Fujita, and Y. Imanishi, J. Colloid Interface Sci., 222, 265 (2000).

9. H. Ueda, S. Kimura, and Y. Imanishi, Chem. Commun., 363 (1998).

10. K. Otoda, S. Kimura, and Y. Imanishi, Biochim. Biophys. Acta, 1145, 33 (1993).

11. M. K. Khoshkbarchi and J. H. Vera, Ind. Eng. Chem. Res., 35, 4319 (1996). 